\title{
IMPLICATIONS FOR THE CORRELATION OF THE HELLENIC NAPPES IN SW AEGEAN: THE GEOLOGICAL STRUCTURE OF THE ARCHANGELOS REGION, RHODES ISLAND
}

\author{
Lekkas E. ${ }^{1}$, Danamos G. ${ }^{1}$, and Skourtsos E. ${ }^{1}$ \\ ${ }^{1}$ National and Kapodistrian University of Athens, Faculty of Geology and Geoenvironment, \\ Department of Dynamic, Tectonic and Applied Geology, elekkas@geol.uoa.gr, \\ eskourt@geol.uoa.gr
}

\begin{abstract}
In the region of Archangelos in central-eastern Rhodes, a nappe sequence from bottom to top consists of: i) Laerma unit, an Oligocene age wild flysch, ii) Archangelos unit, a neritic limestone of Upper Triassic - Mid Eocene age grading through red pelites to a flysch sequence, probably combarable to Ethia unit of Crete, iv) the Profitis Ilias unit, a pelagic sequence of platy limestones and radiolarites of Upper Triassic - Upper Cretaceous age, similar to Pindos Unit and v) the ophiolites. The emplacement of the nappes on the relative autochthonous Laerma unit was carried out in surface conditions and is due to gravitational sliding estimated during Lower Oligocene to Middle - Upper Oligocene.
\end{abstract}

Key words: External Hellenides, geotectonic unit, palaeogeography, wild flysch, Rhodes.

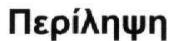

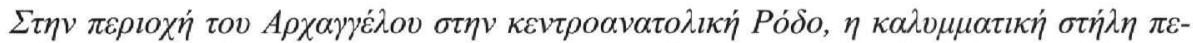

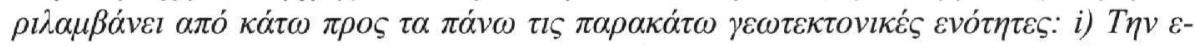

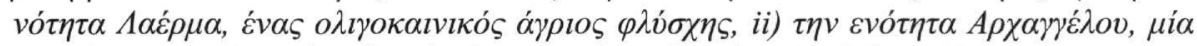

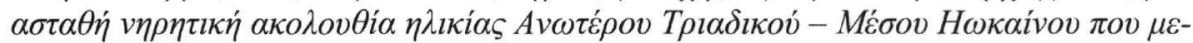

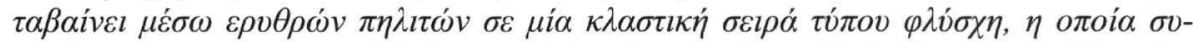

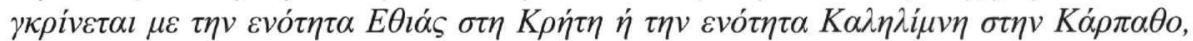

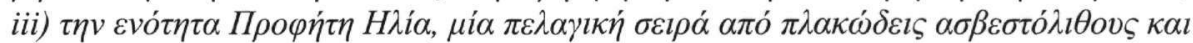

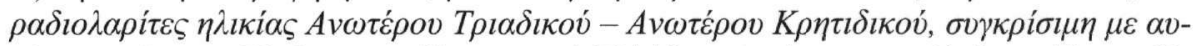

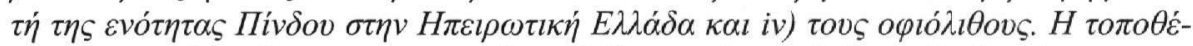

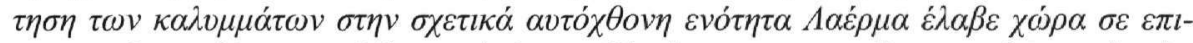

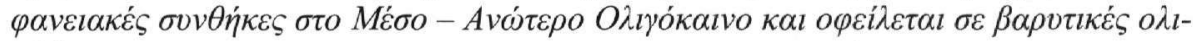
$\sigma \theta \dot{\eta} \sigma \varepsilon l \varsigma$.

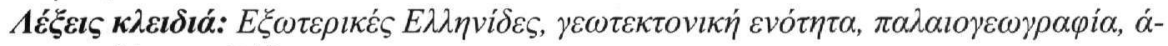

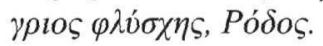

\section{Introduction}

The external Hellenides represent an enlogated arched belt located on the Aegean Arc front, extending from Epirus to the Dodecanese islands comprising of alpine rocks classified in various 
nappes or geotectonic units. The continuations of those nappes from the northwestern to the southeastern end of the arc although it is easy to be tracked through Epirus, Mainland Greece, Peloponnesus and Crete, in the Dodecanese islands however, controversial suggestions exist. This fact is due to the limited surface outcrop of the alpine formations in this region, due to important stratigraphic variations that a unit can present through its geographical development and continuation along the arc and due to the confirmed post-alpine deformation that has led to the formation of Neogene basins that are presently filled by thick sequences of clastic sediments. The aforementioned have resulted in various suggestions through time, regarding the number of units that compose the Dodecanese islands and their correlation to the existing units in Crete and Mainland Greece. Moreover, the fact that the Dodecanese islands are neighbouring to the southwest Turkey and Taurides, triggers the challenge for the correlation of the alpine rocks with those in Asia Minor.

Rhodes is located in the southwestern section of the Aegean arc, is the largest island of the Dodecanese where the alpine rocks present significant surface outcrop and allow better lithostratigraphical observations, though the extended outcrops of the post-alpine deposits have as a result the alpine formations to outcrop as islets. Therefore, various views and suggestions regarding the number of geotectonic units that outcrop on the island and as a consequence their stratigraphy, their paleogeographical location and their correlation to the existing units of the External Hellenides, have been proposed (e.g. Mutti et al. 1970, Aubouin and Dercourt 1970, Aubouin et al.1976, Harbury and Hall 1988, Papanikolaou et al. 1995).

This paper presents the results of the detailed geological mapping on a section of the island, where the alpine rocks dominate, outcropping in great variety. The new stratigraphic and tectonic data presented are the preliminary results of a detailed and lengthy research and contribute significantly to the understanding of the geological structure of the island and the paleogeographical representation of the southeastern Aegean and the correlation of the Hellenides with the Taurides. Therefore, the aim of this paper is to contribute to the knowledge of the Alpine units that are involved in the islands' structure presenting the results of the detailed geological mapping of the region of Archangelos in the central - eastern section of the island.

\section{The Geological Structure of the Island of Rhodes}

In the tectonic structure of the island of Rhodes a series of alpine units are involved that are distinguished from bottom to top as follows (Papanikolaou et al. 1995, Lekkas et al. 2002):

- Lindos Unit. It consists of a cyan to black marble sequence, $400-450 \mathrm{~m}$ thick that grades to red thin platy marbles (cipolline marbles) and grey calcareous phyllites and finally to metamorphosed flysch consisting of greenish schists and phyllites. This transition is estimated to have taken place during the Upper Eocene - Lower Oligocene. This unit represents the lowermost, relatively autochthonous unit of the island.

- Laerma Unit. It outcrops in the area between Attabiros and Lindos, in the central section of the island and corresponds to a unique clastic formation of wild flysch with alternations of clays, pelites, sandstones and bioclastic limestones. Frequenty interbedded horizons of agglomerates and conglomerates with ophiolite elements and psammitic fragments are observed. Within the unit, olistholiths of green igneous rocks, micritic limestones and agglomerated bioclastic limestones are also recorded. The included fauna within the olistholiths determines a formation age of post - Upper Eocene, possibly Oligocene.

- Attabiros - Akramitis Unit. It consists of a pelagic sequence of thin platy and microagglomerated limestones with silex of Upper Jurassic - Middle Eocene age.

- Archangelos Unit. It consists of a thick sequence of massive to thick - bedded limestones and Upper Triassic - Lower Eocene dolomites with Lower Eocene age flysch at the top. 
- Profitis Ilias Unit. It consists of thin platy, micritic, and micro-agglomerated limestones with silex and red marls or radiolarites of Upper Triassic - Upper Cretaceous age.

- Ophiolite Unit. Masses of green igneous rocks (gabbro, diabase, serpentinite) that are frequently followed by radiolarites. This unit is considered to tectonically overly either the Archangelos Unit or the Profitis Ilias Unit.

The above alpine units are unconformably covered by thick clastic sequences deposited in the extensional basins formed after the stacking of the nappes during the Upper Oligocene. These structures become even more complicated by the action of faults that are interrupting the formations continuity (Papanikolaou et al. 1995).

\section{Geological Structure of the Archangelos Region}

The study area is located between the villages of Kolimpia, Arhipolis, Malona and Haraki and covers an approximate area of $100 \mathrm{~km}^{2}$. It includes alpine formations that are attributed to various geotectonic units that are covered by molassic and post alpine sediments (Fig. 1). The results of the detailed geological mapping that was conducted in a 1:10,000 scale are presented in the following paragraphs where the alpine units are described in detail and data are provided regarding the post alpine formations.

\subsection{Alpine Nappes}

\subsubsection{Laerma Unit}

Laerma Unit represents the lowermost tectonic unit of the study area on top of which the rest of the units have been emplaced (Figs 1,2). The largest outcrops of this unit are located in Stegna and Tsagarika, east of Archangelos, in Kavalina location west of Kolimbia and east of the Archipolis. In the area of Laerma (central Rhodes) it exceeds $1000 \mathrm{~m}$ in thickness. It corresponds to a clastic formation that comprises of alternations of clay, yellowish-brown to greenish pelites, calcareous sandstones and bioclastic limestones with turbiditic sedimentary structures. At the lower parts of this formation, interbedded conglomerate and agglomerate horizons that do not exceed 3-5 $\mathrm{m}$ in thickness exist, including angular ophiolithic elements, psammitic fragments and red pelites. Within this clastic formation, olistholiths are also observed with significant size variability that can reach a few tenths of meters in length and thickness. These olistholiths have probably originated either by green igneous rocks, by gypsum or by marly, micritic, pelagic limestone rich in plangtonic foraminifera (Globigerinidae, Globorotalidae) in horizons that do not exceed $5 \mathrm{~cm}$, or by sandstones or finally by clasts and a transferred rich benthonic fauna comprised of Nummulites, Alveolines etc. The thin platy limestones in the Laerma area seems to represent a calcareous intercalation within the pelitic - psammitic flysch matrix, that presently appears as discontinuous due to intense shearing that resulted in boudinage. The included microfauna determine a post - upper Eocene age, possibly lower Oligocene or Oligocene in general.

\subsubsection{Archangelos Unit}

The outcrops of the Archangelos Unit are subdivided in two areas since they present differences in their tectonic structure. The first area is located on the hills south and northeastern of the Archangelos settlement and in the greater region of Tsambika. Stratigraphically it can be divided in two sequences (Fig. 2), a lower volcanosedimentary one and an upper calcareous sequence. The lower one corresponds to a volcanosedimentary formation observed as a tectonic wedge within the calcareous sediments of the unit, located approximately 500-600 m southwest of the Archangelos settlement. This formation is known as the Koumouli formation (Mutti et al. 1970) named after the homonymous mountain in northern Rhodes studied thoroughly by Lekkas et al. (2002). It comprises of two distinct series, a lower one, which is characterized by alternations of pelites, tuffs and rarely sandstones and limestones, within which, bodies of green and purple volcanic rocks are observed in the form of altered pillow lavas, and an upper series which is characterized by 
alternations of pelites, sandstones and bioclastic limestones. The density and the thickness of the carbonate intercalations is increasing towards the upper layers until its domination and contains a variety of fossils such as corals, sponges, echinoids, crinoids and brachiopods. These beds according to Lekkas et al. (2002) are representing the transitional beds towards the carbonate platform of the unit, which is also confirmed by their age (Middle - Upper Triassic). It appears that the lowermost of the beds were deposited on a shoal environment while the uppermost beds under biothermal conditions (Mutti et al. 1970, Harbury and Hall 1988).

The upper section of the unit in the Archangelos area, corresponds to a carbonate platform (Figs 1, 2), with thick-bedded white to grayish-white limestones and dolomites with Dasycladaceae, Cladocoropsis mirabilis, corals and fragments of echinoids and gastropods. In the Tsambika hill as well as in the Outhos location, dark grayish-white, pinkish, platy to massive Upper Cretaceous limestones dominate with rudists, Orbitolinidae and Textulariidae.

The second largest exposure of this unit is in the hilly area of Mesovouno, southeast of Arhipolis settlement. The difference with the Archangelos outcrop is that this one comprises of three large thrust sheets. The two lowermost are comprised of carbonate rocks and flysch while the third one is comprised of limestone. These three thrust sheets are located under the Profitis Ilias Unit (Figs 1, 2). In the areas of Mesovouno and Symiako where the lower thrust sheet outcrops, grayish whitish, white and dark massive or thick-bedded limestones are observed of Liassic age that are grading to thin platy filamentous limestones, the lowest part of which is of Toarsian - Oxfordian age (Fig. 3A). Unconformably to these limestones, medium-bedded platy to massive Upper Cretaceous limestones are observed containing fragments of corals, bryozoa, bivalves and algae. Near the top of the Mesovouni, bioclastic limestones are observed, possibly deposited in a shallow water - high energy environment (Harbury and Hall 1988) while the included microfauna such as Nummulites sp. Discocyclina sp. Globigerapsis and Alveolinidae, suggest open marine conditions of deposition. The aforementioned limestones are grading through small en-echelon faults to brown marly limestones and dark reddish siltstones that represent the lowest part of a flysch, the upper part of which is characterized by alternations of grey - greenish sandstones, polymict conglomerates and marls (Fig. 3B). The thickness of the flysch exceeds $120 \mathrm{~m}$ and a large percentage of the clastic material has originated by the erosion of an ophiolithic nappe.

The flysch in its turn is overlain by the intermediate thrust sheet which comprises of whitish to pinkish neritic limestones with rudists, algae, and corals. These limestones are grading through normal faults to flysch of greenish pelites and yellowish green sandstones. The upper imbrication presents the characteristics of the upper sections of the carbonate rocks of the first imbrication, however without the presence of flysch. Through a set of low-angle normal faults the upper thrust sheet is in contact with formations that are classified to the Profitis Ilias Unit.

The Archangelos unit seems to represent a shallow water sequence which is typical for a carbonate platform (Harbury and Hall 1988). At the end of the Liassic a change in deposition depth is recorded which seems not to de due to local subsidence of the platform but due to large scale tectonic events, as it has been recorded in neighbouring carbonate sequences such as Karpathos (Davidson 1974, Harbury and Hall 1988). It is interesting that a second subsidence event of the platform is observed during the Cenomanian that in combination with the absence of the Lower Cretaceous in all of the outcrops of the unit is indicative of significant uplift and erosion of platform sections, phenomena related to large scale extensional events (Harbury and Hall 1988).

Most researchers support that the Archangelos Unit can be compared to the Tripolitza Unit (Aubouin and Decourt 1970, Leboulenger and Matesco 1975, Papanikolaou et al. 1995) while Aubouin et al. 1976, suggest that it can be compared to the outcrops of the Kalilimni units in the island of Karpathos. However, the initiation of the flysch sedimentation in the Middle Miocene (Mutti et al. 1970), the presence of dark, reddish transitional beds, the frequent alternations in deposition depth that characterize the carbonate sequence (Harbury and Hall 1988), are indicative of significant differences to the Tripolitza Unit. Moreover, because these formations are 
underlying the Profitis Ilias Unit (Pindos), the Archangelos Unit could be correlated either with the transitional units of Ethia type in Crete or with the Kalilimni Unit in the island of Karpathos (Auboin et al. 1976).

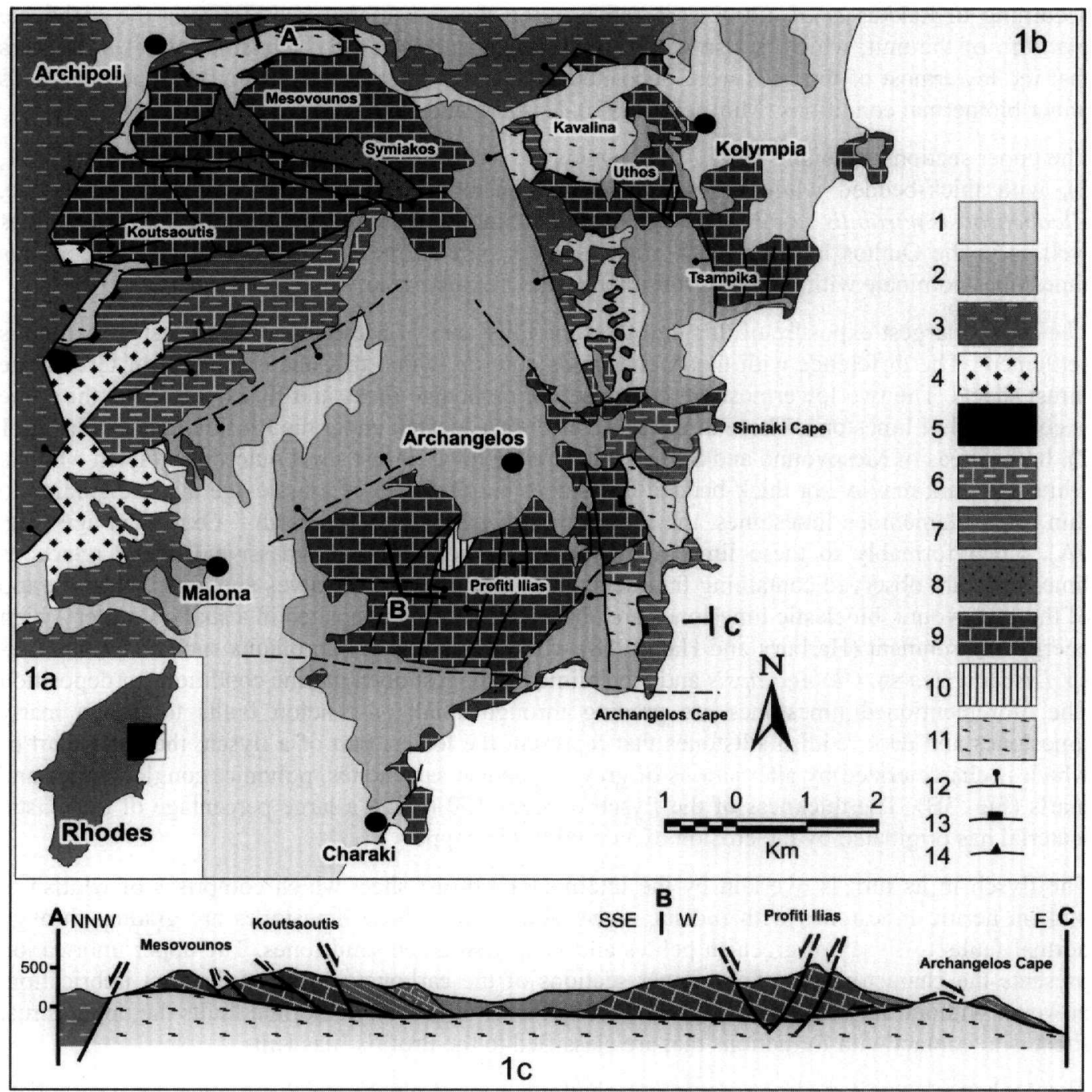

Figure 1 - (1a) The study area is located to the central eastern part of the Rhodes Island. (1b) Geological map of the Archangelos region. 1: Alluvial, 2: Asgourou Fm, 3: Pliocene clastic sediments, 4: Molasse, 5: Ophiolites, 6-7: Profitis Ilias Unit, 6: Upper Cretaceous platy limestones, 7: Platy limestones and radiolarites of Upper Triassic - Upper Jurssic age, 8-10: Archangelos Unit, 8: Flysch, 9: Limestones, 10: Volcanosedimentary sequence, 11: Laerma Unit, 12: High-angle normal fault, 13: Low-angle normal fault, 14: Thrust fault. (1c) Representative geological section of the study area where it is obvious that the upper nappes were emplaced over the Laerma Unit through an horizontal extensional fault

\subsubsection{Profitis Ilias Unit}

The largest outcrop of this unit is observed north of Malona while smaller outcrops are recorded in many locations as in Tsagarika and Kavalina and on the road from Archagelos towards the Stegna beach (Fig. 1). 
It is a pelagic series of Upper Triassic - Upper Cretaceous age, of thin bedded pelagic limestones, radiolarites, pelites and chert nodules (Figs 2, 3D). A full stratigraphic column is recorded north of Malona in the Xerovouno hill where grey, brown-reddish, micritic, platy limestone with nodules and intercalations of greyish to black cherts, are followed by greyish to white, yellowish breccia limestones with intercalations of reddish pelites and dark or reddish chert. Frequently, the breccia limestones contain fragments of echinoderms, shells and algae, possible products of submarine gravitational slumps. This formation in the literature is described as the Elafokambos formation and its lower part in western Rhodes has a Karnian age from Halobia stryciana and Halobia subreticulata (Guernet 1974, Mutti et al. 1970). Above this formation, a sequence of $50 \mathrm{~m}$ thick reddish radiolarites with dark redish pelites and rarely marly limestones is found. Within this sequence a Valanginian age horizon with Calpionellidae is recorded. The latter is grading to thin platy grey yellowish or reddish micritic limestones (Fig. 3C) with marly limestone interbeddings, thin beds of greenish and reddish pelites and cherts that form the Senonian age Messaro formation (Mutti et al. 1970, Danelian et al. 2001)

Another important formation of this unit is located east of Arhangelos, near the coastline where grey to yellowish brown or reddish limestones, interbedded with cherts of Karnian - Lower Liass age (Orompelli and Pozzi 1967, Mutti et al. 1970), overlay the flysch sediments of Laerma. Furthermore, important outcrops are located along and towards the north of the road from Archangelos to Stegna where intensely fractured and folded thin platy limestones with chert intercalations of Senonian age are observed.

These outcrops indicate a low energy deposition environment and deep water. The Xerovouno radiolarites were deposited below CCD with depths that exceeded $2 \mathrm{~km}$ (Harbury and Hall 1988), while the transition to the carbonate sedimentation with calpionellidae and radiolarian in combination with the increase of carbonate beds during Cretaceous indicates a deepening of CCD level. This unit is considered to represent the eastern extension of the Pindos Unit in mainland Greece and Crete (Aubouin and Decourt 1970, Papanikolaou et al. 1995, Lekkas et al. 2002, Danelian et al. 2001).

\subsubsection{Ophiolite unit}

It is observed in the western section of the study area between Mesaros and Limnes and presents a limited surface outcrop (Fig. 1). It comprises of altered peridotites followed by reddish green radiolarites and pelites while the whole sequence exhibits intense fracturing. Although Mutti et al. (1970), suggest that these ophiolite masses are located under the formations of Profitis Ilias Unit, our mapping data do not confirm such a suggestion.

Geochronology with K-Ar in hornblend within these ophiolites in the northern and western Rhodes suggest ages ranging between 75 - $95 \mathrm{Ma}$ with mean values of $87 \mathrm{Ma}$ (Koepke et al. 2003), indicating the lower timescales of the Upper Cretaceous. Similar ages have been suggested for the Taurides ophiolites in southwestern Turkey and more specifically on the metamorphic sole of those nappes and on the doleritic veins included in the ophiolites. Moreover, Rhodes ophiolites exhibit many similarities to the Taurides ophiolites, on the basis of petrography and geochemistry of the trace elements and in their deposition environment. According to the above, Koepke et al. (2003) suggested that these ophiolites cannot be compared to the Cretan ophiolites but to the Cretaceous ophiolitic belt of the Taurides.

\subsection{Molassic Sediments}

These are located on the western and central parts of the study area (Fig. 1). They include greenish sandstones and polymict conglomerates with relatively well rounded clasts that probably have originated by the erosion of an ophiolithic nappe. These sediments lay unconformably on the Profitits Ilias Unit formations and are in contact with post-alpine sediments via normal faults. 


\subsection{Post-Alpine Formations}

\subsubsection{Formation of Pliocene Clastic Sediments}

These sediments are observed to the north and west of the study area (Fig. 1). They consist of thick polymict conglomerates of terrestrial origin alternating with sandstones and clays. Within the latter, thin lignite horizons are observed. The greatest percentage of the clasts has derived from the erosion of Profitis Ilias nappe and the remaining has derived from the rest alpine units. Its age is considered as Pliocene and is possibly expanding towards the Upper Miocene.

\subsubsection{Asgourou Formation}

This formation is outcropping in the central and eastern section of the study area (Fig. 1). Its base is composed of medium cohesion mosaics, sandstones and pelites that exhibit significant lithofacial differentiations. The age of this series is Upper Pliocene - Lower Pleistocene. This series is overlaid by bioclastic limestones, marls and clays that were deposited in an open sea environment and have a Pleistocene age (Mutti et al. 1970, Meulenkamp et al. 1972, Lekkas et al. 2000).

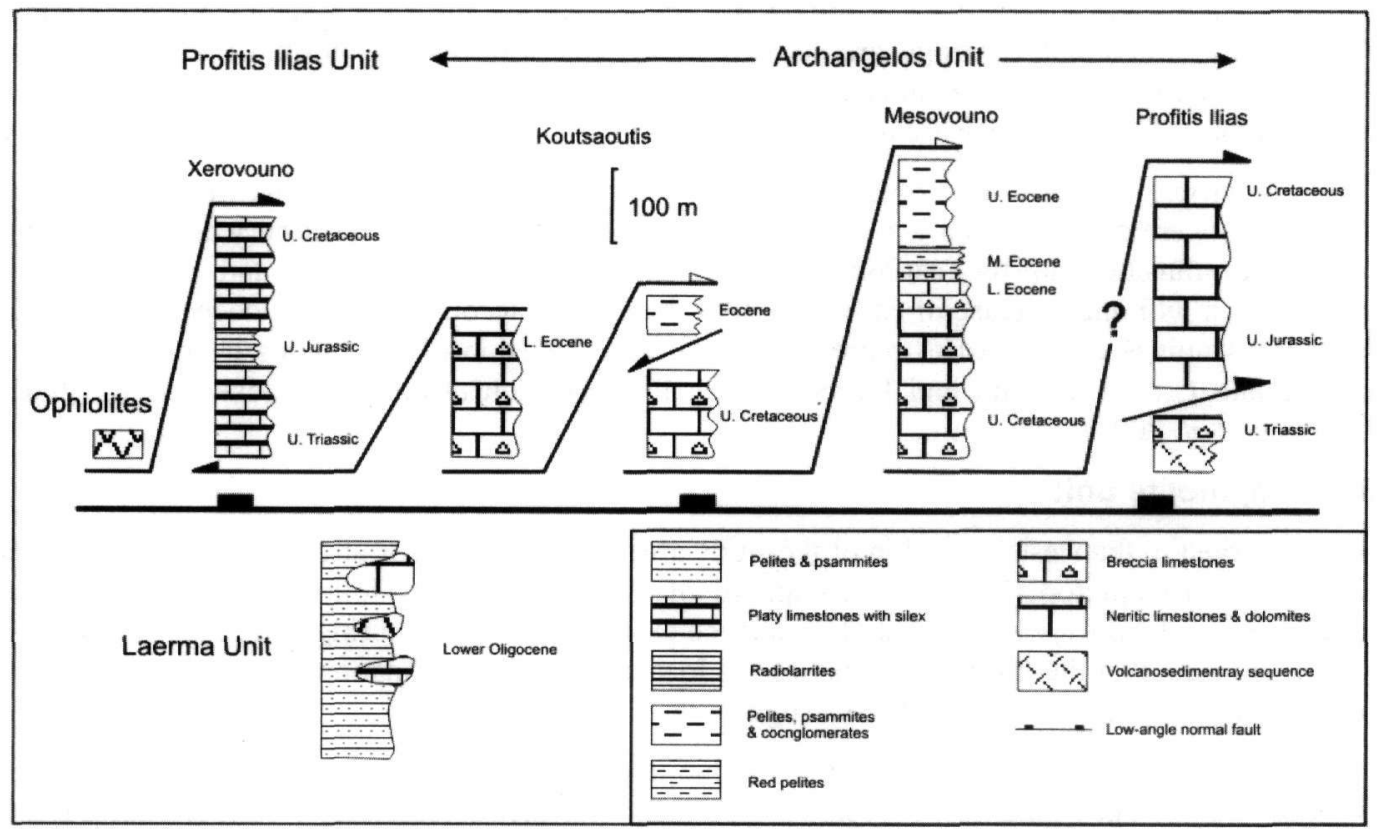

Figure 2 - The stratigraphic coloumns of the geotectonic units that outcrop in the Archangelos region and their tectonic relation

\section{Tectonics}

The principal characteristics of the tectonic structure of the study area are the following: a) all the aforementioned units tectonically overlay the Laerma unit through a tectonic contact that exhibits low angle or is near horizontal and b) the faults that bring the units in contact have an extensional character (Figs 1, 2, 3E). 


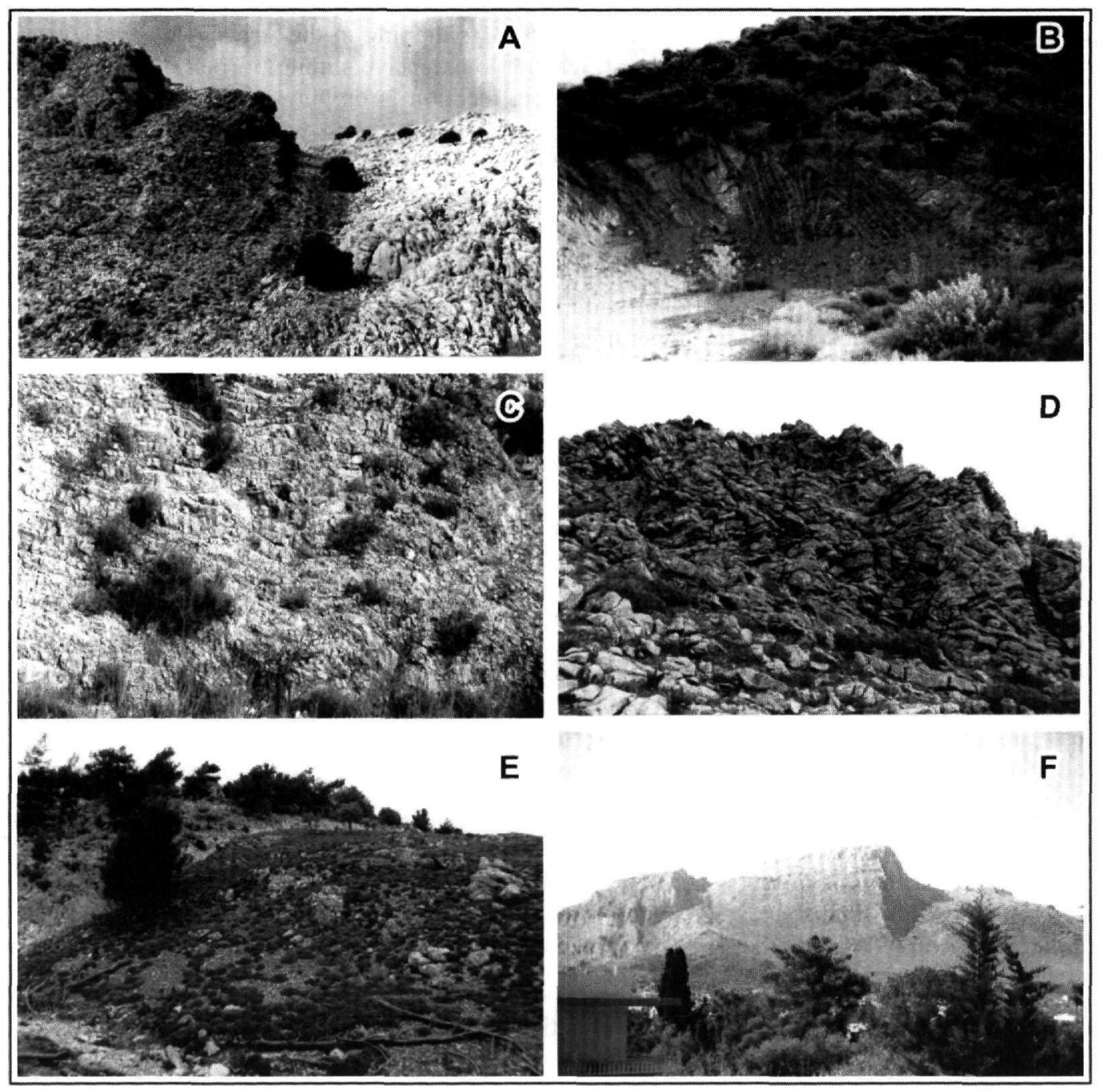

Figure 3 - At the Mesovouno hill, massive limestones of the Archangelos Unit, Liassic in age, are grading to thin platy filamentous limestones, the lowest part of which is of Toarsian -

Oxfordian age. Unconformably to these limestones, Upper Cretaceous thick bedded limestones are observed (A). Alternations of greenish sandstones, polymict conglomerates and marls of the upper part of the flysch sequence of Archangelos Unit (B). Platy limestones of Upper Cretaceous in age of the Profitis Ilias (C). Folded Karnian platy limestones of the Profitis Ilias Unit (D). A high-angle normal fault separating the Archangelos Unit from the

Profitis Ilias Unit (E). Extensional faults in the Profitis Ilias hill, south of Archangelos settlement (F)

As it can be seen in Fig. 1, the carbonates of Archangelos Unit and the pelagic sediments of Profitis Ilias are emplaced on top of the clastic sediments of Laerma Unit through a surface that has a general horizontal character or presents small dip towards various directions. This can be observed in Arhipolis area where the Archangelos limestones that build up Mesovouni are overlying the Laerma Unit through a tectonic contact that dips gently towards the SW. A similar geometry is recorded in the contact between Profitis Ilias Unit and Laerma flysch to the north of Malona. At Koumelo location, south of Stegna, the pelagic limestones of Profitis Ilias Unit overly the Laerma clastics through a surface with intermediate dip angles towards the east with a sense of shear the top to the east. In the area between Stegna and Arhangelos, the contact between the 
neritic limestones of Arhangelos Unit with the flysch, is dipping in the Arhangelos area towards the west and at Stegna area towards the east, leading to extensive sliding of rock masses. Finally, in Kavalina area, this tectonic surface in Kolimbia location is dipping towards the east to SE, allowing the tectonic contact of the clastic sediments of the flysch with the Upper Cretaceous limestones of Archangelos Unit, while in Efta Piges it dips towards the W to SSW allowing the tectonic contact of pelagic limestones of the Profitis Ilias Unit with pelites and sandstones of the flysch.

The above observations lead to the conclusion that the emplacement of the upper nappes onto the Laerma flysch is related to gravitational sliding phenomena. Therefore, these emplaced nappes must be regarded as remnants of the upper units that were emplaced in their present locations after gravity sliding over the clastic sediments of Laerma Unit (Fig. 2). The fact that the age of the uppermost flysch horizons of Laerma Unit is Lower Oligocene and because the base of the molassic sediments has a Middle to Upper Oligocene age, leads to the conclusion that the time interval between Lower Oligocene and Mid - Upper Oligocene is the period when these movements were took place. Regarding the kinematics of this contact, it presents a general direction "the top to the ENE" mainly based on the study of the shear zones within the upper part of the clastics of Laerma Unit directly beneath this tectonic contact.

In the area of Koutsaoutis Mountain, north of Malona settlement, the tectonic contact between the Archangelos Unit and Profitis Ilias Unit is preserved (Figs 1, 3E). It is a high-angle normal fault, of a WSW -ENE strike dipping towards the SSE. Towards its western end it bounds the western limits of the Pleiocene post-alpine basin in the Apollonon area, in the western section of the study area. This fault is dissected by a later NNW-SSE striking fault of high dip angle towards the east that towards the north of Malona is covered unconformably by the Asgouros formation sediments.

An important variation is recorded between the fold axes directions observed within the aforementioned nappes and especially within the formations of Profitis Ilias Unit and those recorded in other regions of the island. It was noted that the principal strike directions were NWSE to NNW-SSE forming an angle of $60^{\circ}-90^{\circ}$ to those described by Mutti et al. (1970) and Harbury and Hall (1988) in other regions of the island. This difference might be due to rotation of the study area during neotectonic deformation.

Another set of folds has a principal N-S direction and is probably related to a compressional deformation phase that was carried out after the deposition of Pleistocene sediments, possibly during Pleistocene. This deformation, created folds with similar directions within the molassic sediments and the Pleistocene formations in the Apollonon basin and the Laerma flysch as it is suggested by the folding of the tectonic contact between the upper units and the parautochtonous Laerma Unit. It is quite possible that this compressional phase could also be responsible for the normal faults with a mean N-S direction that are observed within the carbonates of Archangelos Unit in the Profitis Ilias area (Fig. 3F). These faults give the impression that they were created in order to enable the brittle rocks of the upper units to follow the folding pattern of the more ductile basement (Fig. 1c). As the Pleistocene sediments of Asgourou formation seal the aforementioned faults, we can suggest that these faults were active during the Upper Pliocene - Lower Pleistocene.

The general uplift of the region seems to be due to submarine reverse faults along the southeastern coastlines of the island causing gradual uplift of the area as it is suggested by the fossilized Upper Pleistocene beaches that are presently located in relief that exceed $500 \mathrm{~m}$, e.g. at Profitis Ilias Arhangellou (Pirazzoli et al. 1989, Kontogianni et al. 2002). An additional result of this deformation could be the reverse fault north of Arhangelos where the carbonates of the Arhangelos Unit are overthrusted on Asouros formation sediments. 


\section{Discussion - Conclusion}

Most researchers agree that the lowest tectonic unit on the island is the metamorphosed unit of Lindos (Aubouin and Decourt, 1970) that corresponds either to the Ionian Unit or the Plattenkalk Unit in Crete (Orombelli and Pozzi 1967, Leboulenger and Matesco 1975, Papanikolaou et al. 1995). This unit is tectonically overlain by a "wild flysch" which was named after Papanikolaou et al. 1995 and Lekkas et al. 2000, as Laerma Wild Flysch or Laerma Unit. This unit has a dominant outcrop in the central part of the island of Rhodes and represents the deepest unit in the study area.

In southwestern Rhodes the unit of Attaviros - Akramiti dominates and according to most researchers the sequence of the lithofacies and biofacies are similar to the Ionian Unit in mainland Greece and Crete (Renz 1929, 1955, Orombelli and Pozzi 1967, Mutti et al. 1970, Aubouin and Dercourt 1970, Leboulenger and Matesco 1975). On the contrary, Harbury and Hall (1988), suggested that the paleogeographical region was further inwards from the Archangelos Unit intervening between the latter and the pelagic unit of Profitis Ilias, which was separated from the Pindos Unit suggesting that it comprised a second deep basin further inwards to that of Pindos with the platform of the Archangelos Unit separating the two.

The Archangelos unit comprises of a thick series of massive to thin bedded limestones aged Upper Triassic - Lower Eocene and of a flysch of Middle to Upper Eocene age (Mutti et al. 1970, Leboulenger and Matesco 1975). As the previous unit, this unit is also overlying the Wild Flysch of Laerma. Initially Renz $(1929,1955)$ considered it to belong to the Parnassos- Giona Unit in Mainland Greece. However, Aubouin and Dercourt (1970), Leboulenger and Matesco (1975) and Papanikolaou et al. (1995), mentioned that its tectonic location under Profitis Ilias Unit (Pindos unit) and the Eocene age of the upper horizons of the carbonate series allow to suggest that it corresponds to the Gavrovo - Tripolitza unit. In this present paper, we suggest that this unit can be correlated with the transitional units of Ethia type, having a depositional environment near the inner border of the Gavrovo - Tripolitza platform unit which is affected by intense extensional events that are probably related to the opening of the basin of Profitis Ilias, located further inwards.

The Profitis Ilias Unit comprises of exclusively pelagic sediments such as thin platy limestones with chert intercalations, reddish marls and reddish radiolarites of an Upper Triassic - Upper Cretaceous age (Mutti et al. 1970), which corresponds to the Pindos Unit. The confirmation of the Upper Jurassic age of the radiolarites and the presence of the carbonate horizon with Calpionelles (Danelian et al. 2001) appears to support this suggestion.

The uppermost nappe in the island of Rhodes is composed of ophiolithic rocks that are overlying the Profitis Ilias Unit (Aubouin and Dercourt 1970, Leboulenger and Matesco 1975, Papanikolaou et al. 1995). On the contrary, Mutti et al. (1970) suggested that the ophiolites are located on top of the Arhangelos Unit and under the Profitis Ilias Unit. These ophiolite masses were interpreted as remnants of the Sub-Pelagonian zone nappe (Aubouin and Dercourt 1970) or as remnants of the Pindos Ocean (Papanikolaou et al. 1995).

Recent geochronological data suggest that the Rhodes ophiolites are of Upper Cretaceous age and must correlate to the ophiolites that are observed in southwester Turkey in the nappe region of Lycian (Koepke et al. 2002). This fact brings to light the necessity for the correlation of the Dodecanese geotectonic units to those in southwestern Turkey and especially the Lycian nappes and the parautochthonous metamorphic masses of Baydaglari and Menderes which will allow the decoding of the tectonic structure and the solution to the palaeogeographical representations problem in this section of the Alpine orogenetic belt.

All these units are emplaced through a low-angle extensional fault on the Laerma flysch Unit dated as Lower Oligocene. The emplacement of the nappes on the relatively autochthonous unit of the study area was performed in upper tectonic levels conditions and might be due to gravitational sliding. 


\section{Acknowledgments}

The authors wish to express thanks to the reviewers for their constructive comments and suggestions.

\section{References}

Aubouin, J., and Dercourt, J., 1970. Sur la geologie de l' Egee: regard sur le Dodecanese meridional (Kassos, Karpathos, Rhodes), Bull. Soc. Geol. Fr., (7), XII, 455-472.

Aunouin, J., Bonneau, M., and Davidson, J., 1976. Contribution a' la geologie de l' arc egeen: l' ile de Karpathos, Bull. Soc. Geol. Fr., (7), XVIII, 2, 385-401.

Danelian, T., Bonneau, M., Cadet, J.P., Poisson, A., and Vrielynck, B., 2001. Palaeogeographic and palaeoceonographic implications of new and revised bio-chronostratigraphy constraints from the Profitis Ilias unit (Rhodes, Greece), Bull. Geol. Soc. Greece, 34, 2, 619-625.

Guernet, C., 1974. Le massif de l'Elaphocampos, l'ile de Rhodes et les Hellenides, C. R. Acad. Sc. Paris, 278, Serie D, 813-815.

Harbury, N., and Hall, R., 1988. Mesozoic extensional history of the southern Tethyan continental margin in the SE Aegean, J. Geol. Soc., London, 145, 283-301.

Koebke, J., Seidel, E., and Kreuzer, H., 2003. Ophiolites on the Southern Aegean islands Crete, Karpathos and Rhodes: composition, geochronology and position within the ophiolite belts of the Eastern Mediterranean, Lithos 65, 183- 203.

Kontogianni, V.A., Tsoulos, N., and Stiros, S., 2002. Coastal uplift, earthquakes and active faulting of Rhodes Island (Aegean Arc): modeling based on geodetic inversion, Marine Geology $186,299-317$.

Leboulenger, P., and Matesco, S., 1975. Contribution a l' etude geologique de l' arc egeen: l' ile de Rhodes, Theses 3 e cycle, Universite P. et M. Curie, Paris.

Lekkas, E., Papanikolaou, D., and Sakellariou, D., 2000. Neotectonic map of Greece, 1:100.000 scale: Sheet Rhodos, European Center on Prevention and Forecasting of Earthquakes, Earthquaking Planning and Protection Organization.

Lekkas, E., Danamos, G, Skourtsos, E., and Sakellariou, D., 2002. Position of the Middle Triassic Tyros Beds in the Gavrovo-Tripolis Unit (Rhodes Island,Dodecanese, Greece), Geologica Carpathica, 53/1, 37-44.

Meulenkamp, J., Mulder, F., and van de WeerD, A., 1972. Sedimentary history and paleogeography of the Late Cenozoic of the island of Rhodos, Z. Deutsch. Geol. Ges., 123, 2, 541-553.

Mutti, E., Orombelli, G., and Pozzi, R., 1970. Geological Studies of the Dodecanese Islands (Aegean Sea). Geological map of the Island of Rhodes and Explanatory Notes, Ann. Geol. des Pays Helleniques, 22, 77-226.

Orombelli, G., and Pozzi, R., 1967. Studi geologici sulle isola del Dodecaneso (Mare Egeo). V-Il Mesozoico nell' isola di Rodi (Grecia), Riv. Ital. Paleont. Strat., 73, 409-536.

Papanikolaou, D., Lekkas E., and Sakellariou, D., 1995. Tectonic units and terrane analysis in Rhodos and adjacent Dodekanese islands, Greece, XV Congr. Carpatho-Balcan Geol. Assoc., Symp. Tectonostratigraphic Terranes in CB Region, Athens, September 17-20, 1995, Abstracts, 20.

Pirazzoli, P., Montogianni, L., Saliege, J., Segonzac, G., Thommeret, Y., and Vergnaud-Grazzini, C., 1989. Crustal block movement from Holocene shorelines: Rhodes Island (Greece), Tectonophysics, 170, 89-114. 
Renz, C., 1929. Geologische Untersuchungen auf den Inseln Cypern und Rhodos, Prakt. Acad. Athenes, 4, 301-314pp.

Renz, C., 1955. Dia vorneogene Stratigraphie der normalsedimentaeren Formationen Griechenlands, Inst. Geol. Subsurf. Res., 637pp, Athen. 